$\diamond$ 共通論題 $\diamond$

\title{
共産主義の多様化と将来 一ナショナリズムの一般論化の視座からー
}

沖繩大学教授 落 合 忠 士

\section{1. ナショナリズムのセマンティックス}

$\mathrm{nat}$ i onといら用語は, 語源的には, ラテン語の Natior由来するものである が，それは本来，出生に因づく人間関係，つまり，人種的・部族的社会集団を，事 実上のものであろらと，想像上のものであろうと者問わず，とにかく，血の結合の 上に基礎を犆いた一つの社会集団を意昧していた。1 7 世紀以来 nationは法学者 や国際法学者たちによって, 人種や言語の同一という類の事象と無関係に, 政治的 主権国家の住民を表現する場合に用いられるよらになり，やがてその用語法が一般 的法令にも採用されるよらになった。そしてそれは今日においてはさらに， state あるいは country の同義語として, 一定の主権的組織のもとに統一された一つの 国家社会をも意味するように孛っている。

このよらなnationの多義的不便在救済するため, 19 世紀の初期になって, nat i onalityといら用語が造り出され, 急速にヨーロッ, ハ各語と融合し, それ以 来，nationは政治的主権国家の国民を主として意味し，nationality は, 同一 の言語，共通の習慣を持つ運命共同体としての人間集団に詨して使用するのが正確 な用語法とされるようになった。nationalismという i sm の奏体が，語源的 Natioでカヴァーできない意味内容在表現するよらになったからであろら。ちな みに, 人類史上に就けナショナリズムの発現は, 個人の自由とか, 人間の䙳钽之 いう近代的観念の確立過程と軌を一にして, we-group 意識や，集団的エゴ意識 の覚醒に動機づけられからである。

神や自然に対して人間を表琴するhuman から，人間性在表現するhumanity が，そしてそれを學重する主義としてhumanitarianism があるのと同じく， 民族を表現するnationality から，その存在と個性を相互に尊重し合う意味での natinalitarianism という語が当然想定されてよいが，一般化するに至ってい 
ない。それに代って，nationalism といら用語が，民族的自己主張を表現する 語として使用され，李た，神や自然に対する人間本位の観念を表現する humanism といら語が,一般的用語法としてポピュラー化している。しかしての語のニュアン スについては, humanitarianism との著しい混同が，むしろ一般化しよらと している。

ナショナリズムは“民族主義”，“国民主義”，“国家主義”などと邦訳され， また“国民の精神状態”や，中世的普遍国家からの“近代国家の分立過程”店どと らら含蓄を持って論ぜられるが，そのいずれもが誤っていないなでも，決して十分 な認識とするととができないので，本稿では一応つざのよらに概念規定して，さき へ進むととにする。“ナショナリズムとは，民族の一一したがってをた民族国家の 一個性と民族的人格の維持敊よび発展在志向し，自己の価值と理想と安実現しよ らとする主義主張であり，その生活原理ないし集団的充実生長の運動原理である。

\section{2. ナショナリズムの発現}

(1) 強者に対する反抗性向としての発現

A 強力な影響力を持つ異文化に接した場合

高度な文明を擁し, 強大な武力に担保された異文化飞接する場合の, 弱者の立場 におかれる低文化民族は，異文化ショックともいうべき，梁甚な衝撃を受け，主と して次のような三とおりの詨応克せる。その一は，異文化に全面的に征服されて しまら場合で，同化の進行する一方で，強い文化的反抗が生さ残り続ける。その二 は，交流を一方的に拒否する場合で，鎖国をいし鎖文化という形式をとる。その三 は，異文化の吸収消化飞努め，自文化の向上を企図する場合で，異文化崇拝と自己 文化卑下の心理と共に，一方では，自文化尊重保存の思想が同居する。

B 普遍主義的支配に対する自己主張

この典型は, 中世のキリスト教共同体と神聖ローマ帝国という，単一的普遍的秩 序の中で，デュークやプリンスやキングを中心としを民族的人間集団が，イギリス やフランスといら近代国家に分立していった過程の中に看て取るととができる。

また近くは，イギリスやフランス，オランダやベルギーなどの植民地帝国内の多 くの所領が, 独立国として巣立っていった過程にも見るてとがでさる。 そしてさらにまた，後述するよらに，今日，ソ連帝国主義の支配下にある東欧の 


\section{$<86>$ 共産主義の多様化将来}

(9)

従属体亲( Subordinate System) 諸国も, やがては, ソ連の影響力の弱化を 図り, あるいはその支配からの離脱を追求し, 名実共に備わった独立国の地位走獲 得するに至るであろらというのが，本稿の結論でもあるのである。

（2）弱者に対する支配性向としての発現

この発現は，弱小異民族に対する帝国主義的支配，つまり，強大民族のあくなき 自己発展と勢力拡大の志向の中に見られる。帝国主義的支配の極限は，世界の単一 的普遍的支配に逢着する。そしてててでまた，被支配民族の普遍主義的支配に対す る自己主張一自由・独立の解放運動惹起しないではおかない。これらの例証に ついては，史実上枚挙に艰がない。

\section{3. ナショナリズムの発現形態}

(1) 国家形成志向としてのナショナリズム

このナショナリズムは, すでに触れたように, 中世的普遍的秩序からの近代国家 の分立創建過程と, 帝国主義的版図や植民地加らの民族解放的独立国家建設過程と に, 二大別して観察するととができる。

(2) 国家強化志向としてのナショナリズム

他国との競争意識に駆りたてられ，競争力強化のために，国民を操作したり動員 したりすることにコンセンサスをえられるよう，ナショナルなセンチメント嗢吹 する過程に見られる。その代表的な表現は, 国内異民族の同化による国家統一計画 であったり，国家的団結強化のための教育や宣伝メディアの動員であったりする。

(3) 国家拡大志向としてのナショナリズム

国家的統一が強固で, 軍事的㬰力有し, 没道義的で利已本位的な国家は, 他民 族の犠牲や悲惨を意に介女ず，口実在設けて自己正当化を試み，国家の領域や勢力 範囲の拡大孝追求実践する。この場合, 国際社会の不安定性や, 紛争で多忙をどさ くさは, 帝国主義国の野望を満足させるのに, 好都合な客観状勢を提供する。帝国 主義国は, 排他的な支配圈の拡大を欲求するので, 領土の拡張を第一に求めるが, それが不可能であったり，困難であったりする場合にも，自己の勢力範囲の拡大と 維持に憶欲を燃やし, コミュニケーション共同体, 防衛共同体, 経済貿易共同体 などの設定によって，勢力圏内の牛耳在とろらとするのである。

ここに言う帝国主義とは，“国家の実質的担い手が，国家権力を駆使してしょう 
とする世界の一体的支配の志向であり，より現実的には，その奏践そのものである。” であるとすれば，次には，国家の実質的な担々手，つまりナショナル・エリートと， ナショナリズムの関連の究明に手を着けなけれげをらなくなる。

\section{4. ナショナル。エリートの変遷とナショナリズム}

(1) デェーク，プリンス, キング

中世的普遍秩序を支配したユニヴァーサリズムと，一方の封建的ローカリズムの 分化と統一の過程老通じて，近代国家を創建する意味でのナショナリズムの担い手 は, デューク (duke) や，プリンス(prince) や，キング(king) たちであ った。彼らは 14 世紀中葉から 16 世紀の中葉に加て, 王朝の確立と揆在一にし て，将来民族国家となるべき国家の建設のチャンピオンとなったのである。

ナショナル・エリートとしての王朝の支配の特質は専制的で点り，方りスマ的李 ものであって，多分に宗教性を带びていた。

(2) ブルジョアジー

国民の大多数にいきわたっているある種の精神状態とい5，今日的意味における ナショナリズムの躍動は, フランス革命に始むる。人類は世俗主義を勝利させると とによって, 神や宗教加ら解放され, 個人主義走確立するてとによって, 封建的, 専制的人間関係から解放されて, 自由と平等存獲得し, 自由であり平等であるがゆ えに，友愛の心境にまで到達するととができた。そしてその結果として，大衂心理 の中に祖国を根ゔけるととがでさたのである。

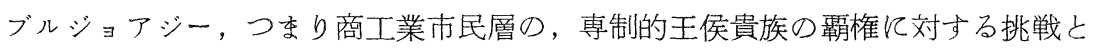
勝利は, イギリスに扫るピューリタン革命と名誉革命の成功によって先鞭がつけ られ、アメリカの独立と, フランス革命と人権宣言によって, 確固をる地歩を築く に至った。とれら契機として、ブルショアジーが新をにナショナル・エリートの 地位在獲得し, 組織的学校教育, 新形式のジャーナリズム, 全国民的徵兵制の祖国 防衛軍の建設などの諸事業が進められ，ブルジョアジーの支配する国家に対する， 大衆の忠誠と献身とが, 人間の美徳として一般に受容されるよらな成功をもたらし たのである。

そして,フランス革命に続くナポレオンの帝国主義戦争の展開と, それに反抗す るョーロッパ諸国に扎て,それぞれのナショナリズムの覚醒が促進されていった。 
$<88>$ 共産主義の多様化と将来

この意味でも, フランス革命は,ナショナリズムの躍動に, 少なからぬインパクト を与えたというととがでさる。

ブルショョアシーの担保するナショナリズムは, 資本主義的経済発展の実質によっ て, 先進的なイギリス，アメリカ，フランスなどによって代表される自由主義的・ 大衆操作的ナショナリズムと, 後進資本主義的な旧ドイッ,イタリア，日本などに よって代表される全体主義的・大衆動員的ナショナリズムに二大別するととができ る。

（3）共産主義的革命社会に和ける前衛党指導者

マルクスの予想と期待を裏切って, 現奏の歷史は, 資本主義国に利可革命でな く, 前資本主義的, 前工業化段階の社会状況にある農業国ロシアや中国に和らて革 命を成功させている。永久革命怒号し, 植民地民族の解放在宣伝し, 後続の共産 主義革命諸国在支配するとのナショナリズムは, 前衛党指導者といらナショナル・ エリートの担保するナショナリズムとして特色づけられている。

人民の自由を抑圧し, 労㗢者の味方だと称して, 労働者を収奪する前衛党のアパ ラーチキたちによって恣意的に変容されるてのナショナリズムは, 共産主義的・全 体主義的・大衆動員的ナショナリズムとして特徽づけるととができる。

旧ドイッ，イタリア，日本存どによって代表された後進資本主義諸国のナショナ リズムと, ソ連や中国などによって代表される前資本主義的後進諸国のナショナリ ズムが，共に，全体主義的で大衆動員的であるが，それぞれの経済的収奪，自由の 抑圧, 教育と宣伝内容の不寛容性など, 大同小異で, いずれがより苛酷で, より徹 底して人間性否定的であるか論の分かれるとてろである。いずれにしても，動員さ れる大衆は客体的存在であって，決して国家の主役ではありえないのである。

(4) 経営者革命社会に打管理者

ここにいら経営者革命社会とは, バーナムのいわゆる経営者革命を遂行したか, (15) 遂行しつつある高度産業社会を意味する。この社会は，ブルショョアジーの支配する 社会の歷史的発展の必然的な通過域であって，今日の先進工業社会は，ブルショョア 支配の社会から経営者革命的社会に移行したか，移行しつつあるといってよい。し のような国家は，新たに経済的・政治的影響力を獲得した管理者リーダーによって， そのナショナリズムが担保されているといらてとができる。そして，てのナショナ リズムの特質は，大衆迎合的かつ大衆操作的である点に求められる。大衆の権利意 
識が高まり，それに裹打ちされた多様支欲求が政治の場に持ち込まれると，国政的 (16) トップ・エリートたちも, 自己保身のために, 大衆の要求をある程度満足させなけ ればならなくなる。しかし大衆の気京な要求は，時として不合理であったり，他 人や他集団や他民族の利益と両立しないとともあるが，管理者リーダーたちは，乙 れらのらちより強い圧力の方傾いていてらとする。そして，乙の帰結は，国際場 裡に㸚いて自己族完結的な, 自国だけの福祉国家化といらナショナリズムの追求と ならざるをえなくなるのである。

一方，大衆はいくら権利の意識に目覚好としても，知識習得の努力に久け，必 要な情報加らも自己柾外に和ちんりがちなので, 新鮮な情報に接し, 知的内容に優 れ，説得の技術を身につけたトップ・エリートたちの操作から，完全に自由である ことはできない。その結果，国際社会に执いて，政治的・経済的利邫得失から想定 されるナショナル・インタレストの追求, あるいはをを, 自文化の卓越性の信念痛 ぞ，情報化され，教育され，宣伝される主義主䛫们同調させられるといら意味で， 大衆操作的ナショナリズムの末端の担い手としての役割在果すようになるのである。

(5) 民族解放闘争の指導者

第 1 次大戦以後, とりわけ第 2 大戦以後に㹁植民地ナショナリズムの沸騰に よって，民族解放闘争に成功して，新たに独立国となった諸国の指導者たちは，わ れわれがこの項で言及しょらとするナショナル・エリートの変遷陔当するもので はないけれども，今日のナショナリズムの特徴あるエリートとしての地位を占めて いる。

彼らの多くは先進国の最高学府での教養を身につけ，民族の悲しみを身をもって 体験し，人民と同じ言葉で語りかけ，大衆の支持をとりつけるととに成功し，大衆 を鼓舞して民族解放闘争に駆りたて，民族解放を達成したものである。しかしてれ ら新興独立国の民度は低く，民主主義の定着する土壤も培養されてはいないので， 大衆動員的ナショナリズムに傾きやすん。

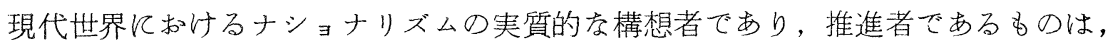
われわれのいら, 経営者革命的社会に数ける管理者たちと, 共産主義的革命社会に おける前衛党指導者たちと，さらに民族解放闘争の指導者たちであり，それらの御 用イデオローグやイデオロギスト (18) たちであるとするととができる。 
$<90>$ 共産主義の多様化と将来

\section{5. スターリンの死とソ連帝国主義の理論的変容}

“共産主義インターナショナル”といら形式在とって外晌かったソ連ナショナ リズムは，マルクス主義の仮面支かぶったその革命的イデオロギーと，強大な武力 在駆使して，極めて短時日のらちに，帝国主義的ナショナリズムに変容していっだ。 ととに, 大祖国戦争と彼らのいら第2 次大戦に勝利して後の帝国主義的拡大には, 計り知れ索いものがあった。スターリンの暴力的存拡大志向に危惧の念を抱いた卜 ルーマンの対応策によって，世界の主要国は，ソ連を中核とするグループと，アメ リカ女中心とするグループの二つに分断され，双極体系の角逐といら戦争瀬戸際状 況水ちんった。

冷戦と呼ばれた米ソ対峙の進行中の 1953 年 3 月 5 日, 一方の元締スターリン が死去した。その結果，スターリンによってのみ可能であったスターリン的を帝国 主義は, 当然変更されざる在えなくなるはずのものであった。果せるかな, ソ連共 産党指導層は, 1956 年 2 月のソ連共産党第 20 回党大会に和いて, スターリン 批判を行孛い, スターリンの抹殺を試みた。そして1957 年6月のいわゆる“反 党グループ”の追放によって，フルシチョフの支配権が確立したものの，6月 28 日にはポーランドのポズナニで反ソ暴動がおこり,さらに 10 月 23 日にはハンガ リーで, 反政府・反ソの暴動が勃発した。フルシチョフはその威信をかけて, 11 月4 日に武力介入し，ハンガリ一国民の自由要求の声を戦車で軪殺してしまった。 しかしフルシチョフはスターリン的支配存可能とする主体的条件を欠如していたの で，ソ連の内外に対する支配の苛烈さも次第に後退していかざるをえなかった。

その内実在知るよすがとなるものが，1957 年 11 月 22 日の“モスクワ宣言” と, 1960 年 12 月6 日の“モスクワ声明”である。その中でもっとも顕著な理 論の修正は，

社会主義への平和的移行を承認したとと。

核戦争に対する恐怖から，両体制間の戦争の不可避性を否定したとと。

社会主義への移行形態の多様性を承認したこと。

社会主義諸国の共産主義への移行に必要物質的基礎として，先進的技術，電化， 機械化，自動化などを受容するといら合理性を示したとと。

政治的独立獲得後の進路の選択は，諸国民の内政問題であるとと者認したとと。 社会主義革命は輸入されるものでなく，外から強制されるものでないととを承認 
したこと。

などの点にみられる。

\section{6. 中ソ対決の双極体系に与えたインパクト}

ソ連共産党指導層と中国共産党指導層の間の理論的不一致は，すでに“モスクワ 宣言”や“モスクワ声明”在採択する会議の席で明確になっていた。ただ全体のた めといら大義名分から, 一時方便的に妥協したにすぎないことが, 後の中り論争の 過程で明らかにされている。この中ソ論争は，国際共産主義陣営の内外の現状認識 に関するもの, スターリン批判に関するもの, 世界熱核戦争防止の可能性ならびに 平和共存に関するもの, 全人民の国嫁論とソ連に晾哄産主義社会建設の現況評

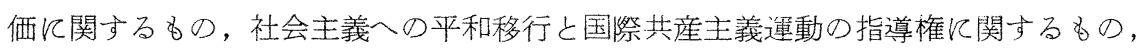
その他多岐にわたって展開されている。そしてそれらのそれぞれの内容が，大なり 小なり，双極構造の弛緩にインパクトを与えているが，その最たるるのは，国際共 産主義運動の指導権に交つわる論難と応酬にあると考えられる。

らを中国側の論難の一部をピック・アップすれば，次のようなものがある。

“ソ連共産党指導部は悪い習慣をもっている。それは批判する者にきまって，む やみイレッテルをはることである。

彼らは，“きみたちは指導権をあらそっている”といっているが，そらではない。 友人のみなさん，あなたがたのてらした誹謗はまったく賢明ではない。あなたがた の言いかたによれば，あなたがたと“指導権”なるものをらばいあっている者がい るかのよらであるが, そらいら言い方は, 国際共産主義運動に, “指導権”なるも のがあって，乙のいわゆる“指導権”が，あなたがたの手中にあるといらとと存臆 面もなく、利ぴらに言明しているととと同じととに去るのではなかるらか。あな たがたのこのよらに，オヤジの党をもってみずから任じているのは，非常に悪い習 慣である。これはまったく不法なととである。

“乙こ数年来の事実が物語るよらに，フルシチョフをかしらとするソ連共産党指

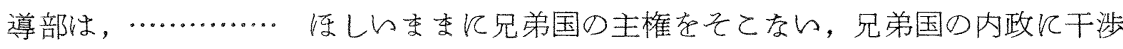

し，転覆活動在すす好て，各方面加ら兄弟国支支配しょらと企てている。

ソ連共産党指導部は，彼らの大国排外主義の政策を利しすめる几あたって，手 
$<92>$ 共産主義の多様化と将来

段をえらばず，ともすれば兄弟国に政治的，経済的に压力，ひいては軍事的圧力を くわ六ている。 (ふ)とみなしている。”

“ソ連共産党指導部は, 新しい独立国を援助する問題で, しばしば大国ショーヴ ィニズムと民族的な利已主義の態度をとり，乙れらの国々の経済的，政治的利益を そてない，従って社会主義国の名誉を傷つけている。”

中国共産党指導翻のソ連共産党指導層に対する反抗は, スターリン以来, 一枚岩 の団結存誇った国際共産主義運動の分裂意味し，ソ連国家の国際的影響力低下を 示唆し, ソ連帝国主義の後退と弱化を招来しないではおかない。

すでに早く、ユーゴスラヴィアの共産党は, 1948 年 6 月 28 日に,前年 7 月に 結成されたコミンフォルム（共産党および労働者党情報局）加除名され，その原 因となった独自の社会主義路線を歩み続けて今日に至っている。

イタリア共産党は, 当時のトリアッチ書記長の指導のもとに, 1956 年 12 月 K, “構造改革論”存定式化して, “社会主義へのイタリアの道”在打出し, ソ連 共産党第 20 回大会に拟て, “社会主義への移行形態の多様性” の承浔をとりつ けた。そして, 1957 年の, “モスクワ宣言”, 1959 年の“ヨーロッパ17ケ 国共産党のローマ・アッピール”，1960 年の“モスクワ声明”を経て, 先進資本 主義国に护る社会主義への移行形態として，すでに定着したモデルになっている。 このような流れの中での中ソ対立は, ソ連自身の直接的な勢力圈の内部の動摇を 誘発し,さらに, 脱ソ連の欲求を駆りたてないでは执かなっ1968年の“プラハ の春”に対して，ソ連は恥も外聞もなく，武力で制圧してしまった。チェコ・スロ バキア共産党は, ハンガリーの党と違って、ワルシャワ条約の枠の中に残るととを 明言し，それから逸脱するととをしょらとはしなかったにもかかわらず，ソ連は， そのささやかな願いさえ許さなかったのである。

チェコ・スロバキアが急ざすぎ，加速度的に独自路線をつき進んだに対し，ルー マニアは, 1952 年の国内モスクワ派の肃清を手始めに, 漸進主義的に脱ソ連の路 線を歩き始めた。そして, 1964 年 4 月の“国際共産主義, 労働運動の問題几お けるルーマニア労働者党の立場に関する声明” ( いわゆる, ルーマニアの独立宣言) によって，その独自路線を内外飞闡明したのである。乙の場合にも，われわれは， 中ソ対立の影響を決して見落してはならない。“これまでのソ連を先頭とする社会 
主義諸国の一枚岩的団結が中ソ論争の発展, 激化により，1960 年代前半に崩れ 去ったととであり，ルーマニアは目ざとくもこの中ソ対立の機を捉え，中ン間の仲 介の名のもとに論争の圈外に立つことで自己の自主的かつ中立的立場を既成事奉と して打ち立て”ていったのである。

またアルバニアは，中ソ対立に際しては，東欧諸国の中で唯一の中国支持勢力と して，反ソの態度を堅持している。

このような国際共産主義運動の多様化, 多極化の傾向は, 米ソの緊張緩和という 上ら交国際的勢力分野加の影響に起因するものであると同時に，东た，東と西の それぞれの内部的国際関係に影響党与えないでは执ない。世界は東と西を問わず， 権力政治的に多極化の方向への歩在進め続けているのである。そして，乙のような 国際環境の中で, 1976 年 6 月 28 ，29 の両日，東べルリンで開催されたヨー ロッパ 29 ケ国の共産党・労働者党の代表者会議に和らて，ソ連は, “ューロ・コ ミュニズム”といら独自の展開を受容しなければをらないすでに, 情勢は変化の度 在深めて進展して行さつつある。

\section{7. 米ソ緊張緩和戦略からのインパクト}

1945 年 2 月 4 日からヤルタに会合したルーズヴェルト，スターリン，チャーチ ルの三巨頭は，11日に“ヤルタ協定一クリミア協定”に署名した。乙の秘密合 意は,アメリカとソ連の二大国が戦後の世界をリードしていくルールの相互了解だ ot。

しかしての了解事項を盾に取ったスターリンの領土的野心が，余りにも法外で底 知れぬものであったため, 早くも1945 年 9 月 11 日からロンドンで開催された西 欧諸国とソ連との外相会議は，10月2日決裂してしまった。てれがアメリカと ソ連が同席した大戦中および戦後の会議における, 最初の決裂であった。以来ソ連 は、スターリンの指導のもとにその帝国主義的ナショナリズムの性格をむき出しに して, 東西間の緊張老激化する挙に出たのである。このようなり連に対し, “全体 主義の脅威”をアッピールするトルーマン・ドクトリンを定立したトルーマンは, ソ連を除外した世界の協力とコントロールを企図し，マーシャル・プランによるヨ 一ロッパ復興に着手した。冷戦戦略の展開である。

しかし, その経済力, 軍事力, マン・パワーのコントロール力などによって, 儎 


\section{$<94>$ 共産主義の多様化と将来}

烈に争われた米ソ冷戦も, “力の限界”といら泠厳な現実加自由ではありえなか った。と同時に, 冷戦そのものが当初のリアルな, 国家理性の国際環境対応的な覚 めた現実認識加ら冕脱し，イデオロギ一的角逐という，不毛の戦場に移行してしま つたのである。そして冷戦になつわるイデオロギー神話の擬制が，東西両陣営内部 での, 国際社会的妥当性走喪失するとき, 硬い双極構造は, 軟らから双極構造へと 一歩後退しなけれげならなくなる。

米ソ両大国首脳の相互理解，あるいは相互尊重的歩み寄りの模索は，1959年 9 月のフルシチョフの訪米に始なる。ととに，25日から 27 日女で，キャンプ. デーヴィッドにあるアイゼンハワーの山荘における会談後の共同コミュニケは, 相 互の相違点在明確にし，それ在相互に認識し合らといら点で，効果はあったが，な んら和解の手助けになる成果は挙げられなかった。そして，1960年にアイゼン 八ワーが訪ソするといら約束も，U2 型スパイ機撃隊事件によって，お流れになっ てしまい，同時にキャンプ・デーヴィッド精神も冷却化してしまった。

1961 年 6 月 3 ・4 日ウィーンで,ケネディとフルシチョフが会談し，4日に共 同声明が発表された。しかし，両者の国際政治の現状認識に大きな隔りがあったた め, 両者の相違在明確にしただけで, 緊張緩和にはなんら役に立たなかった。それ のみか,ケネディ組しやすしと見たフルシチョフは，その後冷戦を激化する挙にさ え出たのである。すなわち，8月13 日にベルリンの壁を構築し，8月30日には 核実験を再開し，さらにキューバ・ミサイル危機に向ってつき進んだ。

1962 年 10 月 $22-28$ 日のキューバ・ミサイル危機は, ケネディの決断によ ってソ連は譲歩を余儀なくされ，フルシチョフはウィーン会議で得たケネディに対 する人物評価の修正在強いられる形となった。12月 12 日のジュネーブ会議で， アメリカ側から米ソ直通電話線 (ホット・ライン) 設置が提案され，63 年 6 月 20 日設置協定に調印され，8月 30 日にワシントンーモスクワ間直通テレタイ ブが開通した。このホット・ラインの設置は, 米ソ間に存在した不信感の一部でも 水解しない限り実現するものではない。ここに二大国間における冷戦の心理構造の 変化を読み取るととができる。

冷戦構造の二つの核, アメリカとン連との相互理解の改善は, 兩陣営間の核戦争 の回避という問題老好転させないでは执かない。東西間の核戦争回避の見通しは， それぞれの陣営の冷戦構造に, 心理的にも物理的にも变化孝呼び起とすととに孝り， 
双極体系の弛緩在招来するはずのものである。まず，フランスと中国が，それぞれ 米ソに対する挑戦在開始した。

1963 年 1 月 14 日, ドゴールは, ナッソ一協定不参加と, イギリスの E E C 加盟在拒否する爆弾声明傺表し, ついで 1 月 22 日には仏・西独協力条約に調印 し, 6 月 21 日には，フランスの大西洋艦隊の引揚げを N A T O 理事会に通告した。 一方中国は，中ソ論争に異状な熱意を燃やして，ソ連の修正主義と帝国主義孝論難 し続けるのであった。そしてフランスと中国は，1964年1月27日外交関係を樹 立し，大使交換走行なったのである。

事ここに至っては，アメリカとソ連の二大国は，計界わコントロールは扔か， 自陣営内のコントロールにも苦慮し, 譲歩在強いられるといら，力不足の状態に落 ち入りつつあるというべきであろう。この傾向とそ，アメリカとソ連両国の必要に 基づく上からの緊張緩和政策の，東西それぞれの冷戦椲造に与えたインパクトとい う法かな。

\section{7. 共産主義の多様化と将来}

（1）共産主義の多様化の当然性

帝国主義段階にまで他民族支配在拡大していったソ連ナショナリズムは，その

“国家死隇論”ひとつをとってみても，マルクス主義から大さく逸脱した理論在展 開している。すでにマルクス主義のインターナショナルな意味内容は，マルクス主 義革命の本家本元のソ連において，ナショナリズムの論理に埋没するといら形で， 変質してしまっている。共産主義インターナショナルといら形式存とって発展して らったソ連ナショナリズムの利己性に対しても，東欧の従属体系諸国は，前衛党エ リ一トの保身上の必要もあって，それ在知りつつ虎の威起借り索がら，被支配国の 地位に甘んじてきた。ソ連や中国および西欧諸国の共産党のナショナル化の例にな らって，東欧諸国でも共産主義のナショナル化は進んでんく。政治的ナショナリズ ムの梁化と共に，共産主義のナショナル化は，今日的国家理性の当然の環境対応的 自己主張の帰結として，世界的に不可避支䖯勢となっている。

個人であれ，民族であれ，したがってまた国家であれ，ての独自性や自由な活動， 自由な自己表現在追求する欲求の延長は，必ず個性の票重という価值観に行き着き， ついで，その当然の結果としてなた個性の多様化在招来しないではおかない。もち 


\section{＜96> 共産主義の多様化と将来}

ろん，人間社会であるから，無制約の拡散の放置は社会の維持を不可能にするので， 全体の中での拡散, 統一の中での遠心, 相互尊重の中での多様化でなけれげならな らととは, 言らをなたないが, 結局, 人間社会に利けるトータルな支配は不可能と なる。ソ連帝国主義に支配されてきた東欧従属体系諸国も，ソ連によって，トータ ルな支配を受けていたわけではない。それゆえ，ソ連の引締めが緩和されれげ，支 配の弱加た分野から, をず, 離反が進行する。表面的・形式的にはともかく, 実 質的には頳目だけでつじつまを合わせておいて, 本来はそれぞれのナショナリズ ムの中に埋没すべき，革命とその後の支配の形式論理にすざない各国の共産主義が， ソ連から離反していくのは, 理の当然の帰結である。もともと, 共産主義には元祖 も家元も純粋形としては存在しなかったのである。

（2）共産主義の多様化と将来

1972 年 5 月 22-30日にわたるニクンン大統領のソ連訪問上, 5 月 29 日 にニクソンとブレジネフとの間に署名された“米ソ関係の基本原則飞関する共同文 書”によって, 米ソ間のデタントは, 形式的には一応軌道に乗った。この文書に含 意されている二大昗点は, 米ソ二国間の不戦と両国外の国際問題に対する共同行動 の約束である。それはある意味では, 第 2 次大戦後の世界の共同処理を構想したヤ ルタ協定に相応して, 冷戦後の世界の共同処理を目図するものであるといらととが でさる。このような米ソ・デタントの空気の中では，もはや東西両陣営に利ける反 ・脱アメリカ, 反・脱ソ連の風潮の生起するととは避けられない。冷戦に呼応して, 一時方便的に双椣体系の一方に身を寄せざるをえなかった東西従属体系諸国も，そ の必要性の崩壊によって，あるいは抑制要因の弱化や承解によって，新をな事態に 対する適応として,ナショナル・インタレスト追求という, 国家理性の要請にもと づんて, 合理的に行動しようとすればするほど, 米ソからの離脱といら意味で, 多 極的世界政治構造，正確には，双極的多様化世界構造の構築に后かって進㐬ざるを えなくなるからである。

共産主義的革命社会に利ける前衛党指導者というナショナル・エリートも, 経営 者革命的社会に和忊管理者といらナショナル・エリートも, 大衆化社会状況の中 で，大衆からの圧力にさらされている。乙の状態の下で，支配の合法性や永続化， リーダーの保身や利益の確保に腐心すればする质ど, 大衆の利益志向, つまりナシ ヨナルな一国完結的福祉国家型利益志向に傾かざるをえず，国益志向の政治や経済 
は，共産主義や資本主義のイデオロギーよりも，実利実益志向のナショナリズムの イデオロギーに，強く傾斜するので，資本主義在標榜する国家の数志け，あるい比 共産党や労働者党の数だけ, 共産主義が存在するととが許容されなけれげならなく 店っていく。

われわれは，人類史の回顧から，

“人類社会は永遠の支配体系の存在というものを決して許さなかった”。

“既存の勢力は必ず新興の勢力によって挑戦をらけてきた”。

という定式化をあえて試る。それゆえ, ソ連共産党に指導されるソ連といら強力な 支配体系も，東欧諸国に典型化しているその従属体系を，永遠に支配し続けること が可能だとは考えられない。それらの諸国家と，ついで，ソ連国内の有力な従属民 族も。やがては民族個性と民族利益の主張という，フランス革命以来の，ナショナ リズム本来のパターンををどり，ソ連の帝国主義支配からの独立を成功させ，名実 共に独立国家として，民族的自己完成への道を歩むようになるであろら。すを，人 類史的教訓から，そらならなけれげならないといらのが，おれわれの，巨視的視野 に立った将来の展望である。（1976 年12月14日）

注

（1）例えば，中世のオックスフォードにおいては，学生たちは，その出身がトレン ト川(The Trent，イングランド東中部の川で, ハンパー川注いでいる)の 北か南かによって，それぞれ別個のnationだとされていたのである。

“Nationalism" A report of Royal Institute of International Affairs. 1963 , xvi i.

この点につんてはスナイダーも，“ラテン語のNatioは，もともと現劵の， あるいは想像上の血の結合の上に基礎を置いた一つの社会的人間集団を意味した” としている。

Louis L. Snyder, The Meaning on Nationalism. 1954 . Rutgers University Press. P. 29.

(2) Carton J, Hayes, Essays on Nationalism. $1926 . \mathrm{P} .3-4$.

(3)乙の意味に打るnationは, “ League of Nations” , “United Nations”あるんは, “Low of Nations”などに見るととができる。 
$<98>$ 共産主義の多様化と将来

(4) Snyder, op.cit. P. 57

(5) Hayes, op. cit. P. 4-5.

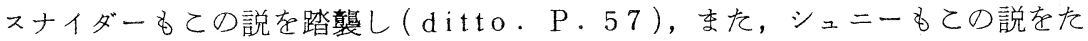
てている。

Heinrich Schnee, Nationalismus and Imperialismus. 1928 .

S. 282 .

(6) ハンス・コーンもとの説をとっており, “われわれの理解しているよらなナシ ョナリズムは, 18 世紀の後半以前にはさかの济らないその最初の発現はフラ ンス革命であった”としている。

Hans Kohn, The Idea of Nationalism, A Study in its Origins and Background. 1967 , The Macmillan Company, P. $3 \& 11$.

(7) 乙の点につんては, 拙著“ナショナリズムの理論と展開”, 1972 年 3 月第 2 刷, 成文堂刊, “第 4 章 ナショナリズムの本質, 第 1 節 ナショナリズムの 概念”を参照されたい。

(8) コーンはとの点とつんて, “Etatism, not nationalism, emerged from the disintegration of medieval universalism”としてい る。 op.cit. P. 188 .

（9）乙の概念につんては，矢野暢稿“多極化と“従属体系”状況の変容一地域主 義との関連一”, 昭和 48 年 5 月, 有斐閣刊, “国際政治 第 48 号” 詳し 々紹介がある。

(10) 乙の点につんては, 前掲拙著の “第 8 章 国家拡張の原理としてのナショナリ ズム，第 2 節 帝国主義の概念”在参照されたい。

(11) ハートマンもとの説をとっている。

Frederick, H. Hartmann, The Relations of Nations, Third Edition, The Macmillan Company, N. Y. 1969 . P. 22.

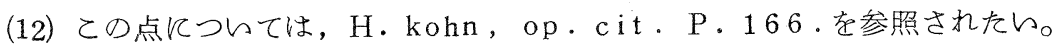

(13) Cf. H. kohn, ditto.P. 10 \& P. 16.

(14) ditto. P. 11 .

(15) 経営者革命の概念については, J ames Burnham, The Managerial Revolution What is Happening in the World, The John Day 
Company, Inc. N. Y. 1941，285PP. を参照されたい。

（16）乙の概念については，拙著“民主政治の理論と展開” 昭和 50 年 1 月, 文化書 房博文社刊，“第6 章 大衆国家の動向”内の関係項を参照されたい。

(17) “福祉国家の理念と政策厓ど, 自己完結的なエコノミック・ナショナリズムを あらわすものはないのである。 板垣与一稿“南北問題とエコノミック・ナショ ナリズム”，東畑精一監修，板垣与一編 “南北問題”，アジア経済講座 第 6 巻， 昭和 46 年 3 月, 東洋経済新報社刊, P. 17 .

(18) われわれは, イデオロギーを創出し, それを唱導する者をイデオローグと呼ぶ。 また, 自分では体系的イデオロギー的教説を構想したり創出したりするととはし ないが, イデオロギース一定の解釈在与え, それ存駆使して, 政治的権力の座を 獲得し, それを維持し続けようとする者をイデオロギー・エリートと呼ぶ。そし て大衆に接触し㐋がらイデオロギ一的実践活動在行なら者たちを，イデオロギス 卜と呼ぶ。

（19）乙の点については, 本学会の第 2 回研究会において, すでに触れておいた。 1973 年版 “ソ連・東欧学会年報, 2 ”の拙稿“ソ連ナショナリズムの性格” を参照のとと。

(20) 1957 年 11 月 14 日から 16 日まで, アルバニア勤労党, ブルガリア共産 党, ハンガリー社会主義労働者党, ヴィエトナム勤労者党, ドイッ統一社会党, 中国共産党, 朝鮮労働党, 蒙古人民革命党, ポーランド統一労働者党, ルーマニ ア労働者党, ソ連共産党, チェコ・スロバキア共産党など 12 の共産党, 労働者 党の代表が参加して，モスクワで会議を開き，11月22日に“プラウダ”紙に 発表した宣言。ユーゴスラヴィアは宣言には参加しなかった。

（21）11月 10 日から会議は開かれていた。世界81 ケ国の共産党, 労働者党の代 表者会議の声明。12月6日に“プラウダ”紙に発表された。

(22) この点についての詳細は, 拙著“ソ連帝国主義の理論と展開”, 昭和 49 年 3 月第 2 刷, 鷹書房刊, PP. 105-6 在参照されたい。

(23) “ソ連共産党指導部とわれわれとの意見の相違の由来と発展 一 一連共産党中 央委員会の公開状を評す—”，1963 年 9 月 6 日，“人民日報”“紅旗”編 集部。外務省国際資料部監修，欧了協会編，“中ソ論争主要文献集”, 昭和 40 年 5 月, 日刊労働通信社刊, PP. $641-2$. 
$<100>$ 共産主義の多様化と将来

（24）“ソ連共産党指導部は現代最大の分裂主義者である一 7 たびソ連共産党中央 委員会の公開畫簡老評す—”1964 年 2 月 4 日，“人民日報”“紅旗”編集 部。同上主要論文集, PP. $800-802$.

（25）“新植民地主義の弁護人一 4 たびソ連共産党中央委員会の公開状を評す一”

1963 年 10 月 22 日，“人民日報”“紅旗”編集部，同上主要文献集，P. 698 .

（26）津嶋冠治稿“ルーマニア一自主外交”，ソ連・東欧総覽刊行会編集委員会編

“ソ連・東欧総覧”, 昭和 48 年 7 月, 読売新聞社刊, P. 356 .

(27) Joyce Kolko and Gabriel Kolko, The Limits of Power;

The World and United States Foreign Policy, 1945-1954, 1972 .

(28) 1962 年 12 月 19-21日, ナッソーでの米英首脳会談で, アメリカが核兵 器の西側における元締的地位を確保することになった協定。

\section{$<$ 質疑応答 $>$}

質問 青山学院大学 寺谷 弘壬

落合会員は，ナショナリズムの研究では，すでに立派な論文（たとえば， “ナショナリズムの理論と展開”成文堂）を発表しておられるので，大変䔋蓄 のある御報告で，勉強になりました。ただ，学会報告の場合，時間に非常な制 約があるため, 歴史的なナショナリズムの発展ではなくして, 現代におけるソ 連のナショナリズムに焦点在しばっていただければ，会員諸君にとって，もっ と，有効ではなかったかと思います。現代という茫漠とした言葉の中に，どの 時期なでさかのばるかは，研究者によってまちまちでしょらが，ナショナリズ ムにおける国益とマルクス・レーニン主義の関係の視座, すなわち,ナショナ リズムとインターナショナリズムの関係は, ソ連在研究していく上で重要な点 であると確信しております。こうした考えで，この共通テーマ在理事会で提起 したようにも記憶しております。

落合会員の平素の御研究では，乙の点が十二分に分析されているのですが， 学会報告では, むしろ省略されて,ナショナリズムの歷史的発展と, ソ連東欧 の将来の二点につんて報告されていたのは，少々残念でした。

ソ連東欧の将来について, “帝国主義の段階にまで進展したン連のナショナ 
リズムの自己主張 一自己表現一個性尊重の要求一国益追求志向几対する 反抗と衝突は，当然の歷史的展開のプロセスに在かならない”，とし，東欧は “ソ連の帝国主義的支配からの独立を成功させる”（レジュメから）と結論し て扣られ李す。社会科学の場合, とくに地域研究の場合, 現状分析を基礎とし て, 未来の予測をするととは, 重要な学問的営み（これは従来日本の学界で軽 視されてきた）であるが，てのスパンはおのずと限界があると思いすす。英語 でforeseeable future といらように, “予見可能な”範囲は, せいぜい 25 年か 50 年さきすでをさすよらです。歴史的を流れでは, 落合会員の“予 測”は，あたっているかも知れませんが，そして私も同じ想い在もつものです が, 学問的㐋プロスペクトとしては, やや短絡的な結論ではないかと感じをし た。

回答 屯ず, ソ連のナショナリズムならびに, ソ連の言うととろのインターナショ ナリズムに関しなしては, 本学会の第 2 回研究会で, “ソ連ナショナリズムの 性格”と題してレポートしてありますので，てのたびは，御指摘のとおり，む しろ作為的に省略らたしました。

ソ連・東欧学会年報（２）の論文も，制限紙数の都合上, 不十分だと感じら れ屯したので, 後日, 安平哲二会員の御好意により, “共産圏問題”誌, 第17 巻第 12 号（1973 年 12 月）に, “ソ連ナショナリズムの源流と性格”と題 して，さらに衍敷（布延）しておきました。また，拙著“ソ連帝国主義の理論 と展開”昭和 49 年第 2 刷, 鷹書房刊, なども, あわせ御参照いただければよ らかと存じます。

さて, 御説の第 2 点についての評価は, 非常に論の分れるとてろだろらと思 らをす。今回の共通論題 “共産主義の多様化と将来”の, むさにキーポイント となるべきものてそ，乙の“将来”の部分にあったと考えます。科学的分析の プロセスでは, 勿論, 将来をターゲット化するてとは忌むべき態度だと思いま す。しかし, 過去の事象やデータの大量観察によって, 帰納的にある命題の法 則性の認識になで到達した場合, 将来的視界の中でその演繹的な思考と適用の 展開を試みるといらアルバイトは, 経験科学の学徒の, むしろ重要な使命の一 つだと信じています。私の師匠の神川彦松先生も, 科学的予見scientific prospectとして，乙の点を重視する立場をとっておられます。このととに 


\section{$<102>$ 共産主義の多様化と将来}

ついては，寺谷会員も同意見の御様子なので安心しをした。

ただ，寺谷会員の言われるforeseeable future が，25 年ないし 50 年であるとする根拠は，例えば，外交政策的対応上の必要といらような，実務 的な理由からですと, 十分理解できるのですが, 経験科学としての社会科学的 見地からは, 劣かなか理解し難らところです。

もし私が，ナショナリズムや，国際政治史的㐋分析の過去在，25年とか， 50 年とかのスパンに限定していたならば, 私のscientific prospectは, 東欧諸国がソ連の支配党脱却して, 自由独立の路線存進むようになるという展 開を否定するような結論になったととでしょう。因に私の視野は，今日的な意 味のナショナリズムの具体的先駆となったフランス革命とフランスのナショナ リズムをも，人間解放思想史上の一駒と見る巨視的なものです。 それゆえにとそ，

“政治的支配の基盤は，下放的化大していく”

“永遠の支配体系といらものは存在しえない”

“既存の勢力は必ず新興の勢力によって挑戦をらける” といら命題の定立が可能となったのだと考えていなす。

そして，共産主義はすでに多様化しつつあります。この現実に即して，ナシ ョナリズム展開の一般論的視座に立って推論すれば, どうしても,レポートの ような結論にならざるをえなせんでした。

しかし，私のてのような立場には，大きな危険が潜在しているととも事丰で す。それは，なんでもかんでも，巨視的な法則性走振回して片付けてしをおら とする教条的態度に傾きやすいというととです。その好例証は，マルキストた ちの唯物史観的ロジックに端的に見られます。てれでは科学的研究とは無縁の

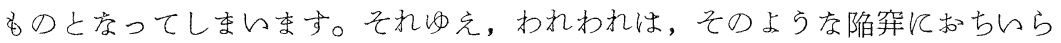
ないように注意しなけれげならないと, 常に自戒しています。

\section{質問}

慶応義塾大学 加藤 寛

たいへん示唆を与えられましたが，少し打教え下さい。

先生の叔考えでいさますと, 多様化の根源を, 個人の価值観と民族の価值観 とを同一視しておられるようですが，てらした面在定するわけではありませ んが，社会としての動さは，個人の多様化と同じにとらえてよろしいでしょら 
か。個人がいかに多様化の方向をもっていても, 社会としては, を個人超 えた方向をもっていると思いなす。（たとえばて業化といったような）いかが でしょらか。

回答 国際政治社会に打る政治単位としての民族，ないし，ある程度の自律的な 行動の格率在有する民族は，民族的個人あるいは団体的個人として規定するて とができ亦すこのような見地に立ちなすと，人類社会内の個人的個人主義と， 団体的個人主義とは, 純粋理論的には, 同質の自由や権利や, 独自の価值観在 追求するととが許容されるはずです。

しかし，現実の個人は，団体の構成員であり，民族成員の一人でしかありま せん。そとで，集団や団体存続上の必要という理由に起因する規制を受けるよ うになるととは, お説のとおり避けられをせん。との点, 報告中の言葉がたり なかったとしたらお詫び致しなす。

ただここで重要なととは, 多椂索価值観の併存在許容するといら風土は, 団 体に対しても個人に対しても, 共通のものとして,できるだけ大切に育て, か つ保持していかな㚈ればならないと考えます。

\section{質問}

NHK国際局 宇野 昌明

個人主義と民族主義の関係一民族主義の将来一

個人主義と民族主義とは，相反する性質孛もつものではない。もし“大衆の 知的向上”が進めば，民族主義は将来消隇すべきものではないでしょらか。

回答人間解放思想史的視座に立てば，人間の尊箃とか，個人的自由の観念が先行 し，民族的人間集団の自己主張が，個人主義的観念の展開途上に出現してきま した。宇野会員のお説のとおりです。なお, この点につきなしては, 加藤会員 の質問に対する回答存も，御参照下さん。

後段の打説は, 実に意味深長をもので, 私もなた興昧を覚え,すでに, 昭和 47 年 5 月の神戸大学にお㥩る日本国際政治学会の研究会で, “大衆動員イデ オロギーとしてのナショナリズムに対する国際政治学的評価”と題する研究報

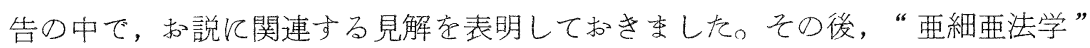
第 7 巻第 2 号に, 同一タイトルの論文在発表しておきました。（昭和 47 年 10 月, 互細亜大学法学部刊) そして, “コスモポリタンの社会への展望” として，“........人間の受ける環境加らの影響は,つなり人間が影響在受ける 
$<104>$ 共産主義の多様化と将来

場所の範囲は, 人間の活動範囲と一致する。いっぽら, 人間の精神内容が充実 するに従って, その認識能力が拡大し, 現実の生活体験在超越して, より広い

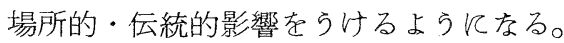

こういらわけで, 人間の行動範囲が拡大すればする在ど，また，抽象的思索 と推論に基づく認識や理解のための能力が生長すればする质ど, 全人類社会的 連帯の認識に到達するよらになるといら意味で, 人間は,よりコスモポリタン

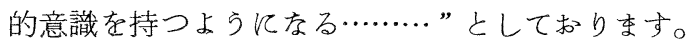

このようなコスモポリタン的人間によって構成される人類社会には，今日的 な意味の, つをり権力志向的な, 排他的ナショナル・インタレスト追求的なナ ショナリズムは, 弱化していくと考えられすす。しかし, ナショナルなセンチ メント, 少なくとす, 文化共同体的なナショナルな自我意識は, 容易に消隇す るととはないと思いすす。

また蛇足ですが，ナショナリズムと民族主義principle of nationality とは同一概念視されないよらお願いできれば幸いです。 